\title{
Knowledge, Attitude, and Self Efficacy of Parents In Providing Education To Prevent Child Sexual Violence In Pontianak City, Indonesia
}

\author{
${ }^{1}$ Huzaid Shauma Zifadlin, ${ }^{2}$ Linda Suwarni, ${ }^{3}$ Selviana, ${ }^{4}$ Vidyastuti, ${ }^{5}$ Widya Lestari \\ 1,4,5 Psychology Study Program, Health Science Faculty, Muhammadiyah University of Pontianak \\ ${ }^{2,3}$ Public Health Science Program Study, Health Science Faculty, Muhammadiyah University of Pontianak \\ ${ }_{1,2,3,4,5}$ A. Yani Street, 111 Pontianak, 78124 \\ E-mail: linda.suwarni@unmuhpnk.ac.id
}

\begin{abstract}
Providing sexuality education to children is one of the primary preventions for preventing sexual violence in children. Parents' knowledge, attitudes, and self-efficacy can affect the provision of this education. The purpose of this study was to describe the knowledge, attitudes, and self-efficacy of parents in providing sexual education to prevent sexual violence in children. This research is quantitative with a cross-sectional approach. The number of samples in this study was 396 parents who have children aged 12-17 years by purposive sampling. Univariate descriptive analysis was used. This study indicates that $56.3 \%$ of parents who have poor knowledge about preventing sexual violence are not supportive attitudes (52.5\%), and 50.0\% have low self-efficacy in preventing sexual violence in children. In addition, $71.5 \%$ of parents understand sexual violence against children in the form of rape and obscenity, and $33.1 \%$ still consider it taboo in providing education to prevent sexual violence in children. It is necessary to increase parents' knowledge, attitudes, and self-efficacy in providing education on preventing sexual violence in children as the primary prevention of sexual violence in children.
\end{abstract}

Keywords: Knowledge, Attitude, Self Efficacy, Child Sexual Violence 


\section{INTRODUCTION}

Children are an investment in the future of a nation, but there are still many problems that arise, including in Indonesia. Cases of violence against children tend to increase from year to year. The 2017 Global Report showed that 73.7\% of Indonesian children aged 1-14 years experience physical and psychological violence at home to discipline (violent discipline) ${ }^{1}$. The number of violence against children recorded from January to June 2020 was 3,928 cases, consisting of sexual, physical, and emotional violence cases, and almost $55 \%$ of them experienced sexual violence ${ }^{2}$. This is exacerbated by the Covid-19 pandemic, which impacts various aspects, including increased child abuse cases during the pandemic. The Ministry of Women's Empowerment and Child Protection recorded a significant increase in cases during the pandemic, including 852 physical violence, 768 psychological, and 1,848 sexual violence. The documented cases of violence against children showed that before the pandemic period, 1,524 children increased to 2,367 children who were victims of violence during the Covid-19 pandemic ${ }^{3}$.

Sexual violence against children is rampant due to the lack of parental knowledge about preventing sexual violence against children ${ }^{4-5}$. The influence of parents is essential in efforts to prevent sexual violence against children, including the attitudes and self-efficacy of parents in delivering education to their children ${ }^{6-7}$. Previous studies have also found that parents' perceptions and attitudes about sexual violence against children influence sexual violence prevention education ${ }^{8-9}$.

To our knowledge, in Pontianak, Indonesia, there are no studies that describe the knowledge, attitudes, and self-efficacy of parents in providing education to prevent sexual violence in children. This information is vital in the city of Pontianak in particular and Indonesia in general because sexuality in eastern culture is a topic that is not discussed and is still taboo so that it has an impact on providing adequate education about sexual health. The purpose of this study was to describe the knowledge, attitudes, and self-efficacy of parents in providing education to prevent sexual violence in children.

\section{METHODS}

This study is a quantitative study with a cross-sectional approach from June to July 2021. The population in this study were all parents who have children aged 12-17 years in Pontianak City (spread over six sub-districts). The sample of this study was 396 people with purposive sampling. Data were collected based on questionnaires that the respondents themselves filled out. Each questionnaire lasted approximately 15 minutes. An interviewer briefly explained the purpose of the study and carefully guided the participants to fill out the questionnaire of the highest quality. The information collected includes knowledge about sexual violence in children and its prevention, attitudes about sexual violence in children, and self-efficacy in preventing sexual violence in children. In addition, they were also asked about forms of sexual violence against children and parents' 
perceptions of sexuality education to prevent sexual violence against children. Data analysis using univariate, which describes the research variables in the form of percentages.

\section{RESULTS AND DISCUSSIONS}

Table 1 showed that most of the respondents were women (62.6\%), married marital status (91.7\%), and middle level of education (44.9\%).

Table 1. Characteristics of the respondents

\begin{tabular}{llcc}
\hline & Characteristics & n & \% \\
\hline 1. & Gender & & 37.4 \\
Men & & 148 & 62.6 \\
Women & 248 & 91.7 \\
2. Marital Status & & 8.3 \\
Married & 363 & 39.2 \\
Widower/ Widow & 33 & 44.9 \\
3. & & 155 & 15.9 \\
Lowel Education & & 178 & $\mathbf{1 0 0 . 0}$ \\
Middle & Total & 63 & $\mathbf{3 9 6}$ \\
\hline
\end{tabular}

Table 2 reveals that the highest percentages of respondents had poor knowledge about child sexual against violence and its prevention (56.3\%), poor attitude regarding the education of preventing child sex against violence (52.5\%), dan low efficacy to deliver the information regarding child sexual against violence $(50.0 \%)$. In addition, $71.5 \%$ of parents understand sexual violence against children in the form of rape and obscenity, and $33.1 \%$ still consider it taboo in providing education to prevent sexual violence in children.

Table 2. Univariate Analysis

\begin{tabular}{llcc}
\hline \multicolumn{1}{c}{ Variable } & n & \% \\
\hline 1. & Knowledge & & \\
& Poor & 223 & 56.3 \\
& Good & 173 & 43.7 \\
2. Attitude & & \\
& Poor & 208 & 52.5 \\
& Good & 188 & 47.5 \\
3. & Self Efficacy & 198 & 50.0 \\
& Low & 198 & 50.0 \\
& High & & 71.5 \\
4. & Form of child sexual violence & 283 & 28.5 \\
& rape and obscenity & 113 & 33.1 \\
& others & & 66.9 \\
\hline Education of Sexuality & 131 & $\mathbf{1 0 0 . 0}$ \\
\hline
\end{tabular}

This study has provided insight into the description of parents' level of knowledge, attitudes, and self-efficacy in providing education to prevent sexual violence in children. Although most parents 
still think that sexual violence is only in the form of rape and obscenity. This impacts educational materials for preventing sexual violence against children when they only consider that the only form of sexual violence is rape or sexual abuse. The results of this study also found that most parents do not think it taboo in sexuality education. However, they are still confused in conveying the instruction and still lower their self-efficacy. The results of this study can contribute to increasing the knowledge, attitudes, and self-efficacy of parents in preventing sexual violence against children both at home and at school.

This study found that parents are still taboo in discussing sexuality with their children. They are supported by previous studies which state that parents in Asia are still taboo in talking about sexuality to their children ${ }^{10-11}$. Therefore, many children seek information from other sources (other than parents), such as the internet or social networks. However, it can provide misinformed answers, which can lead to misconceptions about child sexual abuse. Therefore, unofficial information can lead to failure to protect children from sexual abuse.

Parents have an important role in preventing child sexual abuse ${ }^{7}$. This study found that parents have low self-efficacy in delivering education on preventing sexual violence to their children. In contrast, self-efficacy is an essential and dominant factor in influencing a person's behavior. This is supported by previous studies which stated self-efficacy as a significant predictor of a person's behavior $^{12-15}$.

The results of this study can serve as initial data that is used to design interventions for further parents in increasing knowledge, attitudes, and self-efficacy in delivering education on preventing sexual violence in children, especially in Pontianak City and Indonesia in general. Differences in concepts and forms of child sexual violence can affect children's delivery of sexual violence prevention education. It can lead to information bias that causes primary prevention to be not optimal.

Several limitations must be considered. First, our study was a cross-sectional study; it will challenging to infer causality between risk factors and outcomes. Second, self-reported questionnaires can lead to memory bias and social desirability response bias. Our interviewer is trained to recognize and minimize bias. Third, we did not investigate the children's knowledge about child sexual violence against violence but only focused on the knowledge, attitudes, and self-efficacy of parents.

\section{CONCLUSION AND SUGGESTIONS}

This study indicates that $56.3 \%$ of parents have poor knowledge about preventing sexual violence, are not supportive attitudes (52.5\%), and 50.0\% have low self-efficacy in preventing sexual violence in children. In addition, $71.5 \%$ of parents understand sexual violence against children in the form of rape and obscenity, and $33.1 \%$ still consider it taboo in providing education to prevent sexual violence in children. It is necessary to increase parents' knowledge, attitudes, and self-efficacy in 
providing education on preventing sexual violence in children as the primary prevention of sexual violence in children.

\section{REFERENCES}

1. Global Report, 2017: Ending Violence in Childhood.

2. Medistiara, Y.(2020). Menteri PPA: Dari Januari-Juni 2020 ada 3.928 kasus Kekerasan Anak.

3. Kemen PPPA. (2020). 3000 Kasus Kekerasan Anak selama Pandemi Covid-19. https://tirto.id/kemen-pppa-catat-3000-kasus-kekerasan-anak-selama-pandemi-covid-19-fK3j.

4. Hermawati, I., Sofian, A. (2018). Kekerasan Seksual Oleh Anak Terhadap Anak. Jurnal Penelitian Kesejahteraan Sosial, 17(1): 1-20.

5. Rudolf, J., Zimmer-Gembeck, M. J., Shanley, D. C., Walsh, K., Hawkins, R. (2018). Parental Discussion of Child Sexual Abuse: Is It Associated with the Parenting Practices of Involvement, Monitoring, and General Communication? J Child Sex Abus, 27(2):195-216.

6. Gustina, E., Sofiana, L., Ayu, S. C., Wibowo, M., Wardani, I, D. (2020). Violence Determinant on Teenagers in Yogyakarta. KEMAS, 16(1): 1-10. E

7. Rudolph, J., Zimmer-Gembeck, M. J., Shanley, D. C., Hawkins, R. (2018). Child Sexual Abuse Prevention Opportunities: Parenting, Programs, and Reduction of Risk. Child Maltreat, 23(1): DOI: $10.1080 / 10538712.2011 .627584$.

8. Mathoma, A.M.; Maripe-Perera, D.B.; Khumalo, L.P.; Mbayi, B.L.; Seloilwe, E.S. Knowledge and perceptions of parents regarding child sexual abuse in Botswana and Swaziland. J. Pediatr. Nurs. 2006, 21, 67-72. [CrossRef]

9. AlRammah, A.A.; Alqahtani, S.M.; Elzubair, A.G.; Al-Saleh, S.S.; Syed, W.; Khalid, A.A.; Al-Shammari, H.H. Factors associated with perceptions of child sexual abuse and lack of parental knowledge: A community-Based cross-Sectional study from the Eastern Province of Saudi Arabia. Ann. Saudi. Med. 2018, 38, 391-398. [CrossRef]

10. Do, L.A.; Boonmongkon, P.; Paek, S.C.; Guadamuz, T.E. 'Hu Hong' (a bad thing): Parental perceptions of teenagers' sexuality in urban Vietnam. BMC Public Health 2017, 17, 226. [CrossRef]

11. Suwarni, L., Ismail, D., Prabandari, YS., and Adiyanti, MG. (2015). Perceived Parental Monitoring on Adolescence Premarital Sexual Behavior in Pontianak City, Indonesia. Int J Public Health Sci, 4(4): 211-219.

12. Balkaran, Sabina, "Impact of Child Abuse Education on Parent's Self-Efficacy: An Experimental Study" (2015). Walden Dissertations and Doctoral Studies. 1432. https://scholarworks.waldenu.edu/dissertations/1432

13. Lestari, EM., Suwarni, L., Selviana., Mawardi. (2021). Factors related to Covid-19 Prevention Behavior in Pontianak City. Health Journal, 11(3): 335-340. 
E-ISSN: 2808-5361 http://e-journal.fkmumj.ac.id/
Proceeding The First Muhammadiyah InternasionalPublic Health and Medicine Conference

14. Apriaji, Y., Suwarni, L., Selviana., Mawardi. (2021). Determinants of Covid-19 Prevention Behaviour in the Pontianak City Mosque Congregation. Indonesian Journal of Public Health, 16(1): 14-19.

15. Solehati, T., Rahayu, S., Adillah, H., Triyani, D., Novita, G., Murti, A., Hermayanti, Y., Kosasih, C., \& Mediana, H. (2021). Intervention in Parents to Prevent Sexual Abuse in Children: Literature Review. Jurnal Ilmiah Permas: Jurnal Ilmiah STIKES Kendal, 11(2), 265-274. https://doi.org/https://doi.org/10.32583/pskm.v11i2.1334 